\title{
Por uma arqueologia crítica das imagens em Aby Warburg, André Malraux e Jean-Luc Godard
}

For a critical archeology of images in Aby Warburg, André Malraux and Jean-Luc Godard do Rio Grande do Sul (UFRGS). Professora adjunta do curso de Comunicação Social da Universidade Luterana do Brasil (ULBRA). E-mail: gabriela.mralmeida@gmail.com. 
Resumo: este trabalho apresenta uma releitura da proposta de arqueologia crítica da história da arte formulada por Georges Didi-Huberman, para refletir sobre três distintas experiências de investigação de imagens conduzidas ao longo do século XX: o Atlas de Imagens Mnenosyne de Aby Warburg (1924-1929); o Museu Imaginário de André Malraux (1947-1953) e a série História(s) do Cinema de Jean-Luc Godard (1988-1998). O objetivo é compreender de que modo os procedimentos desenvolvidos por cada um deles, a partir de um certo entendimento das noções de tempo e montagem nas imagens, dialogam com a proposição de Didi-Huberman e constituem efetivamente um exercício de arqueologia crítica.

Palavras-chave: imagem; arqueologia crítica da história da arte; Aby Warburg; André Malraux; Jean-Luc Godard.

Abstract: this work offers a rereading for the proposition of a critical archeology of art history formulated by Georges Didi-Huberman, in order to speculate on three distinct investigative experiences conducted throughout the XX century: Aby Warburg's Mnemosyne Atlas (1924-1929); André Malraux's Museum Without Walls and Jean-Luc Godard's series Histoire(s) du cinéma. The aim is to comprehend how the procedures developed by each of them, from a certain understanding of the notions of time and montage in images, may establish some dialogue with Didi Huberman's proposition and constitute effectively an exercise of critical archeology.

Key words: image; critical archeology of art history; Aby Warburg; André Malraux; Jean-Luc Godard. 


\section{Introdução}

Em alguns de seus livros, como Remontages du temps subi - L'oeil de l'histoire, 2 (2010) e Ante el tiempo. Historia del arte y anacronismo de las imágenes (2011), o historiador da arte francês Georges Didi-Huberman refere-se a um modo de estar diante das imagens para investigá-las e defende o exercício de uma arqueologia crítica da história da arte. Não se trata de uma proposição metodológica de aplicação universal, embora a fala do autor esteja sempre perpassada por críticas às metodologias de análise das imagens baseadas exclusivamente na historiografia. Mais do que um novo método, o que Didi-Huberman propõe, influenciado por Walter Benjamin, é uma postura de rompimento com a linearidade do relato histórico e a insurgência contra uma narração excessivamente ordenada e cronológica (a que se refere como a superação de um "tempo pacificado").

O autor afirma que uma imagem a respeito da qual não se pode dizer nada é uma imagem à qual não dedicamos tempo suficiente e coragem de nos re-inquietarmos. É que, para Didi-Huberman, por mais antiga que seja uma imagem, diante dela o presente e o passado não param de se reconfigurar, e o que resta é pensá-la como uma construção da memória. Assim, uma arqueologia crítica passaria por um olhar subjetivo capaz de interrogar a história da arte, de perceber os diferentes tempos que perpassam as imagens e os valores de uso do tempo na disciplina histórica que pretendeu fazer das imagens o seu objeto de estudo.

Este artigo apresenta uma releitura desta proposta, para identificar aproximações entre as experiências de Aby Warburg com o Atlas de Imagens Mnemosyne (1924-1929); André Malraux com o museu imaginário (1947-1954) e Jean-Luc Godard com a série História(s) do cinema (Histoire(s) du cinéma, 1988-1998). O objetivo é compreender de que modo as investigações conduzidas por Warburg, Malraux e Godard em diferentes momentos do século XX constituem uma arqueologia crítica das imagens, e como a proposição de Didi-Huberman dialoga com elas.

Embora sejam materiais de naturezas diferentes - um atlas de imagens que servia à pesquisa iconológica do seu criador, um conjunto de livros sobre história da arte e uma obra audiovisual, respectivamente - os três casos escolhidos compreendem exercícios de pensamento com e por imagens, possibilitados pelo surgimento e popularização das imagens técnicas (fotografia, cinema e vídeo). Em cada um se faz presente, de forma distinta, um forte caráter de exame das imagens, de percepção dos seus anacronismos e de valorização de um escrutínio não-historiográfico. 


\section{Arqueologia crítica da história da arte segundo Georges Didi-Huberman}

Didi-Huberman ocupa um papel central no estudo das imagens ao assumir o saber visual como ambiente possível para problematizar a história (tanto da arte quanto do homem), especialmente quando se torna o principal divulgador da obra do alemão Aby Warburg. Desde os ensaios presentes no livro $\mathrm{O}$ que vemos, o que nos olha $(1998)^{2}$ até o recente Cascas $(2013 a)^{3}$, o que se vê é um minucioso esforço, ao mesmo tempo intelectual e poético, de tratar as imagens não como objeto, mas como "ato e processo".

Ao pensar a imagem como ato e processo, dissociá-la da condição de simples objeto e se negar a confiná-la em conceitos (ou seja, adjetivá-la e defini-la como "coisa"), Didi-Huberman valoriza a experiência da relação de um sujeito com a imagem - o "inquietar-se diante da imagem”. Esta relação envolve, para além do “ver”, uma dimensão fenomenológica que obriga a relacionar o sensível e o inteligível, ou seja, a considerar como uma determinada imagem atinge este sujeito.

Não se trata de uma abordagem da recepção das imagens, mas sim de uma crença no poder que elas guardam de surpreender sempre, "isto é, de suscitar novas maneiras de falar e de pensar” (DIDI-HUBERMAN, 2006, tradução nossa). E isto vai ocorrer, para o autor, especialmente quando as imagens são postas em relação umas com as outras e em função do movimento gerado por este gesto de aproximá-las. A proposta levantada aqui é justamente discutir essa forma de colocar imagens em relação que aparece nos procedimentos de Aby Waburg, André Malraux e Jean-Luc Godard que tento relacionar.

Como afirma Antonio Oviedo, em Didi-Huberman “toda imagem é portadora de uma memória, acomoda uma montagem de tempos heterogêneos e descontínuos que, sem dúvida, se conectam e se interpenetram" (OVIEDO, 2011, p. 11, tradução nossa). A partir desta premissa, surgem algumas questões que pautam boa parte das investigações de Didi-Huberman: que relação entre história e tempo a imagem nos impõe, e qual a consequência deste processo para a história da arte como disciplina? Se, diante de uma imagem, estamos diante do tempo, de que classe de tempo se fala? E mais: "De que plasticidade e de que fraturas, de que ritmos e de que golpes de tempo se pode tratar nesta abertura da imagem?" (DIDI-HUBERMAN, 2011 , p. 31, tradução nossa).

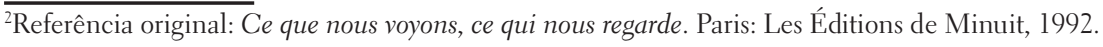

${ }^{3}$ Publicado originalmente em livro, com o título Écorces (Paris: Les Éditions de Minuit, 2011). No Brasil, o texto foi publicado na revista Serrote, $n^{\circ} 3,2013 a$.
} 
Como autor, Didi-Huberman costuma dividir com os leitores os percursos investigativos que conduziram às questões que o norteiam - e elas, por sua vez, parecem muitas vezes mais relevantes do que as possíveis respostas a que pode chegar ao tentar respondê-las. Assim, é possível acompanhar num livro como o já citado Ante el tiempo a experiência pessoal que o levou a uma outra questão de fundo bastante fundamental: em que condições um objeto ou um questionamento histórico novo podem emergir de um contexto já excessivamente conhecido e documentado? ${ }^{4}$. $\mathrm{Ou}$, como o próprio autor coloca: "Como estar à altura de todos os tempos que esta imagem, diante de nós, conjuga sobre tantos planos? E, primeiro, como dar conta do presente desta experiência, da memória que ela convoca e do futuro que carrega?” (DIDI-HUBERMAN, 2011, p. 32, tradução nossa). Ou seja, algo que chamou a atenção de Didi-Huberman ao olhar um afresco de Fra Angelico do século XV transformou-se num verdadeiro problema epistemológico para o qual a solução por ele apontada é o exercício de uma arqueologia crítica da história da arte que passa, inclusive, por questionar até mesmo o objeto de estudo da disciplina.

As interpretações mais comuns das obras artísticas buscarão nos fatos históricos e no próprio legado da história da arte dados contextuais que permitam uma melhor compreensão das imagens, sejam elas um afresco de Fra Angelico ou uma outra obra qualquer. No entanto, o que Didi-Huberman afirma é que esse tipo de leitura será sempre limitada por não reconhecer a existência e mesmo a necessidade de um anacronismo que existe em toda imagem e, consequentemente, em toda atividade de interpretação de uma imagem. A perspectiva é de abertura da imagem à percepção do anacronismo e dos tempos pelos quais ela é entrecortada.

As imagens carregam uma temporalidade muito complexa e nela "se chocam e se esparramam todos os tempos com os quais está feita a história." (OVIEDO, 2011 , p. 21, tradução nossa). Deste modo, o seu estudo não pode se restringir apenas a uma história dos conteúdos presentes na imagem ou a uma história dos seus aspectos formais. Mesmo que o historiador busque a concordância de tempos ao analisar uma imagem, o que resta, para Didi-Huberman, não é o tempo do passado, mas sim o da memória que é convocada e interpelada pelo ato de estar diante da imagem. Se a imagem guarda diversos tempos anacrônicos e convoca necessariamente a história, o procedimento analítico passa por desmontar, montar e remontar estas temporalidades (exercício a que o autor chama de conhecimento por montagem), desconstruindo um curso contínuo e valorizando os desvios, bifurcações e descontinuidades que se fazem presentes no ato de estar diante de uma imagem e conseguir enxergar nela

\footnotetext{
${ }^{4}$ Neste caso específico, trata-se de um relato memorialístico da sua experiência, cerca de quinze anos antes da publicação do texto, diante do afresco Madona das sombras, uma representação da Conversa Sagrada pintada por Fra Angelico por volta de 1440 em uma parede do convento de São Marcos, em Florença.
} 
muitas camadas de tempos.

É importante alertar novamente que o conhecimento por montagem de que fala Didi-Huberman não corresponde a um método a ser reproduzido. Menos ainda o autor sugere ou incentiva que se impute aos seus procedimentos qualquer universalidade num sentido metodológico estrito. Não se trata de uma fórmula a ser seguida em um novo caminho da história da arte como disciplina, mas sim de uma postura, uma revisão de conceitos e processos e uma proposta de abordagem das imagens que não passa por constituir um conjunto de regras ou um modus operandi a partir do qual as imagens devem ser analisadas.

A premissa de que partimos na formulação desta pesquisa e que será aprofundada nas próximas seções é a seguinte: a proposição de Didi-Huberman foi exercitada ao longo do século XX, de algum modo e de diferentes formas, por Aby Warburg, André Malraux e Jean-Luc Godard. Cada um à sua maneira, como investigadores das imagens, eles colocaram em marcha um modo de analisar imagens desmontando e remontando fragmentos carregados de historicidade, com a consciência - e mesmo a assunção - de um anacronismo que é por eles valorizado e transformado em potência de criação de conhecimento. Não se furtam de assumir as diferentes temporalidades das imagens, tanto no âmbito da montagem de tempos a que se refere Didi-Huberman, quanto no âmbito da montagem como gesto de colocar imagens em relação e produzir choque.

\section{O colecionismo como traço comum a Warburg, Malraux e Godard}

No seio de variadas práticas artísticas, a ideia de coleção e o ato de colecionar remetem predominantemente (mas não exclusivamente) ao surgimento das instituições museísticas, num âmbito coletivo, e à figura do colecionador, num âmbito individual. No entanto, em alguns momentos as duas se misturam, a exemplo dos inúmeros casos de museus que têm origem em doações de colecionadores particulares, ou mesmo quando uma coleção individual se torna pública ao fazer parte do acervo de um museu.

A figura do colecionador foi descrita por Walter Benjamin em alguns de seus escritos, como num trecho das Passagens chamado O Colecionador e também nos textos Desempacotando a minha biblioteca e Escavar e recordar ${ }^{5}$. Benjamin era ele próprio um colecionador que se referia com certa frequência à sua coleção de livros de uma maneira que remete sempre a um contexto maior que o da sua indivi-

${ }^{5}$ Ambos publicados em BENJAMIN, 2012. 
dualidade. Colecionar é, para o autor, um ato quase mágico, uma vez que retira um objeto das suas funções utilitárias e lhe confere um outro caráter, que se estabelece no contato com os demais objetos da coleção:

É decisivo na arte de colecionar que o objeto seja desligado de todas as suas funções primitivas, a fim de travar a relação mais íntima que se pode imaginar com aquilo que lhe é semelhante. Esta relação é diametralmente oposta à utilidade e situa-se sob a categoria singular da completude. O que é esta "completude"? E uma grandiosa tentativa de superar o caráter totalmente irracional de sua mera existência através da integração em um sistema histórico novo, criado especialmente para este fim: a coleção. E para o verdadeiro colecionador, cada uma das coisas torna-se neste sistema uma enciclopédia de toda a ciência da época, da paisagem, da indústria, do proprietário do qual provém. (BENJAMIN, 2006, p. 239)

Colecionar, para Benjamin, diz respeito a recolher objetos que acabam se tornando um registro da própria história do colecionador, de modo que o ato de colecionar é mais relevante do que a coleção em si. Há uma relação com algo que não está circunscrito apenas ao objeto, que são os rastros daquilo que ele foi antes de se tornar parte da coleção: “A época, a região, a arte, o dono anterior - para o verdadeiro colecionador todos esses detalhes se somam para formar uma enciclopédia mágica, cuja quintessência é o destino de seu objeto." (BENJAMIN, 2012, p. 234).

Ao relatar a sua própria experiência de colecionador de livros, Benjamin narra alguns passos que percorreu no processo de aquisição de obras - um critério totalmente arbitrário para falar do colecionismo, ele admite, mas que foi o que o motivou a escrever o que chama de "um discurso sobre o colecionar" (BENJAMIN, 2012, p. 232-233). Saem das caixas de livros que desempacota e escorrem para o texto as recordações mais pessoais, sobretudo dos lugares que Benjamin associa a cada título (na maioria das vezes, as cidades onde comprou cada livro e as memórias que guarda de cada uma delas).

O autor considera o caráter pessoal do ato de colecionar tão importante que o fenômeno "perde o seu sentido à medida que perde seu agente" (BENJAMIN, 2012, p. 240). Ou seja, Benjamin reconhece o mérito social e a utilidade científica das coleções que são compartilhadas, mas atribui uma pessoalidade indissociável ao ato de colecionar. Para ele, o indivíduo colecionador é uma figura em processo de desaparecimento, na medida em que as coleções são cada vez mais tornadas públicas e, ainda que permaneçam como conjuntos de objetos reunidos a partir de determinados critérios, não garantem a centralidade do papel do colecionador.

É possível pensar no colecionador hoje a partir de outros parâmetros e dife- 
renciá-lo, talvez, do acumulador (especialmente quando se considera que nunca se arquivou tanto). É possível que não se trate mais da figura descrita por Benjamin, que estabelece inclusive uma relação de posse com os objetos que adquire. Boa parte do que se coleciona e arquiva atualmente - inclusive imagens - não é composta apenas por objetos físicos, e provavelmente o que diferencia o acumulador do colecionador é a natureza dos usos que cada um faz daquilo que guarda. Segundo Márcio Seligmann-Silva, a cultura do colecionismo e da acumulação se tornou uma obsessão que remete a uma tendência memorialista do nosso tempo:

Falar hoje de arquivos, de colecionismo, de listagens e de musealização tornou-se quase uma obsessão. Faz parte de nossos atuais rituais acadêmicos recordar esta nossa cultura da memória. É imperativo hoje descrever e tentar entender esta nossa nova paisagem arquival. É como se de repente todos nós tivéssemos ficado conscientes de que cultura é memória: uma asserção que já era verdade para pensadores como Aby Warburg, Walter Benjamin, Maurice Halbwachs, Freud, entre tantos outros. Mas é claro que falar que cultura é memória não é o mesmo que falar que cultura é arquivo, ou ainda, que cultura é musealização. (SELIGMANN, SILVA, 2008, p. 104)

Trato aqui a noção de colecionismo é tratada como um gesto que perpassa uma parte importante das práticas artísticas do século XX. Se, como afirma Seligmann-Silva (2006 e 2008), a arte do presente é mais do que nunca uma arte da memória, que se articula numa associação entre arquivamento e rememoração, é necessário considerar, no caso das imagens, alguns dados de contexto. Com a ubiquidade dos equipamentos de captação de imagens, nunca se produziu um volume de imagens tão grande quanto no presente. Ao mesmo tempo, também nunca houve uma quantidade tão grande de imagens destinadas a serem "apenas" arquivadas (no sentido de guardadas e nunca mais acessadas; produzidas sem nenhum outro fim que não seja meramente a sua própria captação e arquivamento). Ou seja, não é possível desconsiderar as mudanças tecnológicas que praticamente nos "condenam” a produzir arquivos, a conservar tudo o que for possível e a experimentar uma "museificação da vida", que ocorre ao mesmo tempo em que novos arquivos são produzidos.

\section{Conforme Néstor Fernandez:}

[...] as práticas contemporâneas que conduzem a uma proliferação de museus e de objetos museificantes não implicam uma correspondência com a experiência do passado, mas sim se relacionam com a impossibilidade do presente de sentir-se parte do relato histórico, pelo qual produz rastros, marcas que a própria sociedade considera relevante imprimir aos relatos constitutivos e identitários, alcançando seu maior desenvolvimento na contemporaneidade, consumando um tipo de "com- 
pulsão arquivista" e uma museificação da vida, através do crescente apogeu de museus consagrados aos mais diversos objetos. (FERNANDEZ, 2010, tradução nossa)

Como veremos, o que diferencia os hábitos de colecionismo de Aby Warburg, André Malraux e Jean-Luc Godard da mera acumulação é justamente a maneira como se apropriam daquilo que lhes serve de matéria-prima - os objetos que colecionam são submetidos a um minucioso escrutínio. E o que os aproxima de Benjamin é a negação de um tratamento historiográfico dos seus motivos, dos seus temas de investigação (respectivamente, a arte e história da arte e o cinema e a história do cinema). Neste conjunto de intelectuais abordados, as coleções de imagens da arte e do cinema servem à criação e revelam, em alguma medida, traços do colecionador benjaminiano que se transforma em artista com deslocamentos que, ao desmontar e remontar, descontextualizam as imagens e as colocam em relação de outras maneiras, conferindo-lhes outros sentidos e assim, por consequência, gerando um modo bastante particular de examiná-las.

\section{Aby Warburg e o Atlas de Imagens Mnemosyne}

Embora a ligação de Godard com André Malraux pareça mais óbvia, por motivos cronológicos e pela atuação de Malraux no imbróglio com Henri Langlois na Cinemateca Francesa ${ }^{6}$, numa dimensão conceitual é possível traçar um paralelo entre o projeto envolvido na realização de História(s) do Cinema e o Atlas de Imagens Mnemosyne de Aby Warburg: para uma história da arte sem palavras (em Warburg), uma correspondente história do cinema também sem palavras (em Godard). Ambas através das imagens.

Nem Godard e nem Warburg abandonam a palavra. Refiro-me aqui ao fato de que, tanto em Warburg quanto em Godard, a palavra não é o principal meio através do qual cada respectiva história é contada. Warburg produz, com o Atlas, um enorme quebra-cabeça praticamente desprovido de texto escrito, composto por um conjunto de 63 pranchas que reúnem, cada uma, um grande número de fotografias de obras de arte e reproduções de materiais tão diversos quanto livros, anúncios, recortes de jornais e revistas e mapas (somando cerca

\footnotetext{
${ }^{6}$ Em fevereiro de 1968 a demissão de Langlois do cargo de diretor da Cinemateca deu origem ao que ficou conhecido como "l'affaire Langlois". Um significativo grupo de artistas e cineastas, inclusive aqueles ligados à Nouvelle Vague, lançou um movimento de apoio à permanência de Langlois no cargo, mobilizando também a comunidade cinematográfica internacional. O episódio é considerado uma "antecipação" do Maio de 68 na França no meio artístico-cultural.
} 
de 970 excertos, ao todo $)^{7}$. Godard, por sua vez, produz um ensaio audiovisual que também é um grande quebra-cabeça composto por materiais audiovisuais, fotográficos, iconográficos e textuais de diversas procedências, mas com aspecto semelhante a uma "colagem" em vídeo.

O Atlas de Imagens Mnemosyne e a Biblioteca Warburg de Ciência da Cultura são dois projetos aos quais Warburg dedicou muitos esforços, no intuito de propor à história da arte um novo conjunto de procedimentos a partir dos quais ela pudesse se tornar uma verdadeira ciência da arte e da cultura, que passasse não por uma iconografia cronológica apenas, mas sim por uma análise de como migram e se transformam as imagens - como sobrevivem, afinal - ao se deslocar por culturas e períodos históricos distintos. Um modo ao qual Agamben (2009, p. 132) se referiu como uma ciência nova e "sem nome".

A questão da sobrevivência das imagens se tornaria uma chave fundamental do pensamento de Warburg, sob o termo Nachleben, que diz respeito a uma sobrevivência no sentido de ressurgências ou reaparições, das passagens ou dos deslocamentos sofridos pela imagem através do tempo, que fazem com que ela se torne uma forma em constante mutação, uma espécie de rastro, mais do que um objeto.

Para entrar mais especificamente nos procedimentos investigativos de Warburg, é possível identificar um traço em comum, bastante definidor, que permeia tanto o Atlas Mnemosyne quanto a biblioteca Warburg (que não são projetos distintos): ele não organizava e nem associava livros, imagens ou obras de arte em função de critérios como similaridade, cronologia ou escolas e movimentos. Neste aspecto reside a particularidade metodológica que será constituinte da obra warburguiana e matriz da sua proposta de ciência da arte.

Na biblioteca de Hamburgo, onde trabalhava, Warburg podia exercitar um pensamento associativo por meio de imagens, dispondo nas estantes de grandes pranchas (de um metro e meio por dois, compostas por tábuas de madeira forradas com panos pretos, onde fixava fotografias de quadros e obras de arte) reproduções fotográficas procedentes de livros, publicidade, jornais e outros materiais gráficos. A partir destas pranchas, organizou o Atlas Mnemosyne. Assim, de uma recusa a uma história da arte cronológica e estetizante e de uma concepção de imagem incomum ao seu tempo, Warburg criou um projeto em que o estudo da arte e da cultura se deu por meio de reproduções técnicas de obras. Importante explicar que tão funda-

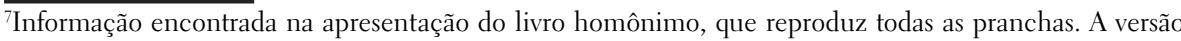
utilizada durante a pesquisa foi a publicada na Espanha: WARBURG, 2010. No entanto, o Atlas pode ser consultado integralmente no site Engramma, dedicado ao projeto: http://www.engramma.it/eOS2/ atlante/.Acesso em 08/10/2016. 
mental para o Atlas quanto as próprias pranchas eram as fotografias das pranchas que Warburg fazia, o que insere no projeto mais um nível de mediação e denota uma despreocupação com valores bastante importantes para a história da arte até então, como originalidade e raridade.

Três diferentes versões do Atlas foram produzidas por Warburg em vida e há um certo consenso sobre o caráter laboratorial do material, como se fosse uma fase documentada de um trabalho de investigação, nunca uma obra concluída. A organização das pranchas nas três versões foi feita a partir de um conjunto de cerca de duas mil reproduções, nas quais Warburg trabalhou em contínuas recomposições (ele montava, fotografava e depois se permitia desmontar e remontar, alterando posições, excluindo algumas reproduções e incluindo outras, etc), num estudo das imagens que passava necessariamente por colocá-las nesse movimento.

\section{André Malraux e o Museu Imaginário}

Mais famoso pela sua trajetória na literatura e na política do que por seus ensaios de teoria da arte, André Malraux se tornou conhecido após o lançamento de A Condição Humana, em 1933; por sua atuação na resistência francesa durante a Segunda Guerra Mundial e pela proximidade com o general Charles de Gaulle, o que lhe rendeu o posto de ministro de Estado na França em duas ocasiões: entre 1945 e 1946 foi Ministro da Informação e entre 1959 e 1969 foi Ministro da Cultura. Mas o que interessa especialmente aqui são os seus escritos sobre arte e o conceito de museu imaginário.

O museu imaginário de André Malraux diz respeito principalmente a um lugar mental, um conjunto de obras de arte que os indivíduos podem conhecer e acessar mesmo sem frequentar museus e que chega a eles por meio das reproduções fotográficas e dos livros. No entanto, o museu imaginário também ganhou materialidade na forma de algumas obras bibliográficas de autoria do próprio Malraux. Como teórico, propôs e efetivamente praticou um pensamento visual através do estudo da história da arte baseado em fotografias de obras, com algumas aproximações e várias diferenças e particularidades em relação aos procedimentos de Warburg para a elaboração do Atlas. Isso se deu, inicialmente, em um texto seminal publicado em 1947 (Le musée imaginaire) como parte da trilogia La Psychologie de l'Art ${ }^{8}$ e, poste-

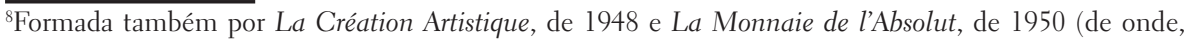
inclusive, Godard toma emprestado o título de um dos episódios de História(s) do cinema). Em 1951, uma nova edição foi lançada, com o título Le Voix du Silence, reunindo os três textos originais em versões expandidas, e com o acréscimo de mais um, Les Metamorphoses d'Apollon. 
riormente, numa obra composta por um conjunto de três volumes produzidos entre 1950 e 1953, os “livros-álbuns” Le Musée Imaginaire de la Sculpture Mondiale?.

Nos ensaios de crítica de arte em que buscou aprofundar a noção de museu imaginário e de certa forma dar materialidade ao conceito que tinha formulado, Malraux problematizou a função dos museus enquanto espaços codificados que permitem o acesso das pessoas a obras de arte que, antes da sua existência, ficavam restritas aos colecionadores, marchands ou membros da nobreza. Em seguida, percebeu - e valorizou - na fotografia um meio através do qual a arte se tornaria acessível a um número infinitamente maior de indivíduos. E estes, a partir do contato com as obras nos museus e também por meio das reproduções, formariam os seus "museus imaginários". Por último, concebeu seus "livros-álbuns" a partir de uma visão bastante heterodoxa da história da arte, em que não se furtou de alterar as obras de que trata ao manipular as fotografias destas obras (por exemplo, em termos de enquadramento ou iluminação). É como se Malraux, através dos seus procedimentos metodológicos e das escolhas que fez para compor os livros, criasse novas obras, distintas das originais, embora compostas por fragmentos delas.

Assim, além de propor uma comparação entre obras de períodos históricos e locais totalmente distintos, tentando estabelecer relações entre elas, Malraux também agia concretamente sobre as imagens, por exemplo, "transformando" pequenas peças em objetos grandes em função de reenquadramentos, mas também criando textos de forma integrada às imagens, para alcançar uma determinada forma no layout dos livros e na disposição gráfica de todo o material.

Talvez esta falta de pudor se deva à própria concepção de museu de Malraux. Para ele, a instituição museística em si já é um lugar de "dessacralização" da arte, pois as obras reunidas num museu, mesmo quando organizadas de forma cronológica e didática, foram retiradas de suas funções originais e seus contextos sociais, locais e históricos e "transformadas" em quadros, pinturas e retratos. Com um tom jocoso, ele questiona: "De que nos importa quem foi o Homem com o Capacete ou o Homem com a Luva na vida real? Para nós, seus nomes são Rembrandt e Ticiano" (MALRAUX, 1974, p. 14, tradução nossa).

Para o autor também é central a consciência de que o museu é sempre um acervo limitado e que, ao apresentar um determinado conjunto de obras de forma necessariamente lacunar, o museu evoca inclusive aquelas que faltam. Esta lacuna

${ }^{9}$ Os volumes se chamam Le Musée Imaginaire de la Sculpture Mondiale, Le Musée Imaginaire de la Sculpture Mondiale - Des Bas-Reliefs Aux Grottes Sacrées e Le Musée Imaginaire de la Sculpture Mondiale - Le Monde Chrétien e foram lançados pela editora Gallimard, entre 1952-1954, na coleção La Galerie de la Pleiade, da qual o próprio Malraux era o diretor. 
seria justamente aquilo que potencializa a reprodução da obra de arte por meio da fotografia como algo positivo na visão de Malraux, pois produz um novo tipo de relação entre o espectador e as obras. Embora não use o termo montagem para falar do museu, de certa maneira Malraux o concebe como um lugar onde se pensa por montagem, uma vez que o visitante será compelido, observando as obras, a colocá-las em relação e estabelecer conexões:

Há mais de um século a nossa relação com a arte tem se tornado cada vez mais intelectualizada. O museu de arte convida à crítica de cada uma das expressões que reúne; e a um questionamento sobre o que possuem em comum. (MALRAUX, 1974, p. 14-15, tradução nossa)

A chave da noção de museu imaginário reside, então, na ideia de que o conhecimento dos espectadores compreende um espectro muito mais amplo do que os museus conseguem dar conta, em função das limitações que lhes são próprias. Faltam aos museus tudo aquilo que não pode ser removido de seus locais de origem, que não pode ser exposto ou que o museu não pôde adquirir. Deste modo, a possibilidade de reprodução das obras através da fotografia e das técnicas de impressão contribuiria para a formação do museu imaginário de cada indivíduo, inclusive dos próprios artistas, que criam sempre a partir do que já foi feito (mesmo aquilo com que o artista não teve contato diretamente, mas que habita o seu museu imaginário ainda assim).

Se Malraux já supunha o museu como um espaço de “dessacralização” da arte, passa então, com o museu imaginário, a questionar de que maneira a fotografia obriga a repensar a noção de obra de arte, e vai também colocar em prática nos seus próprios livros aquilo que surge nos seus questionamentos teóricos. A manipulação de quesitos técnicos da fotografia como angulação, foco e luz são determinantes para salientar aspectos que muitas vezes nem mesmo os autores das obras de arte pretenderam destacar, permitindo a criação de vínculos de familiaridade entre as obras que só existem quando elas são fotografadas e dispostas lado a lado, estabelecendo-se um tipo de comparação. A reprodutibilidade técnica é utilizada como um fator de descontextualização, a ponto de ele afirmar, numa célebre frase: "nos últimos cem anos (excetuando-se a atividade dos especialistas), a história da arte tem sido a história daquilo que é fotografável” (MALRAUX, 1974, p. 30, tradução nossa).

Apesar de se referir ao caráter "fictício" da arte na medida em que os seus objetos são sistematicamente alterados em escala, Malraux (1974, p. 24) não percebe de forma negativa esta manipulação fotográfica. Para ele, ao mesmo tempo em que, ao serem reproduzidas fotograficamente, as obras perdem quase tudo o que lhes era 
específico (suas cores, textura, dimensões e volume), elas ganham em familiaridade e estilo comum, de modo que o diálogo que se estabelece entre diferentes temporalidades e culturas por meio do contato entre as obras é o fundamental.

É como se os livros-álbum fossem o próprio museu imaginário transformado em objetos, com o propósito de afirmar que o estudo da arte só é possível por meio do contraste, da comparação - inclusive e especialmente - estabelecendo relações entre obras que, a princípio, não teriam relação alguma (e tudo isso possibilitado e potencializado em função da fotografia). Em Warburg e Malraux, a fotografia assume um papel central ao ser a principal responsável por um estudo da história da arte que se dá através de imagens (fotográficas) das imagens (obras artísticas).

\section{Jean-Luc Godard e a série História(s) do cinema}

Apesar do que sugere o título da série, História(s) do cinema não apresenta propriamente uma historiografia do cinema. Trata-se de um grande ensaio produzido por meios audiovisuais em que convergem a história do século XX e uma memória do cinema tão pessoal e afetiva quanto permite a coleção de materiais da qual Godard partiu.

Produzida pela emissora francesa Canal+ entre os anos de 1988 e 1998 e dividida em oito episódios, História(s) do cinema tem tempo total de 268 minutos de duração. No entanto, um primeiro esboço da proposta da obra teve origem alguns anos antes, num conjunto de conferências ministradas pelo cineasta no Conservatório de Arte Cinematográfica de Montreal, em 1979, em que Godard partiu do pressuposto de que uma verdadeira história do cinema deveria ser contada através de imagens e não apenas da palavra (como fazia a historiografia tradicional do cinema $)^{10}$.

Em linhas muito gerais, o extrato visual dos episódios é composto basicamente por: a) imagens estáticas pré-existentes; b) imagens em movimento pré-existentes ou gravadas especificamente para a série e c) inscrições textuais na tela, que aparecem em cartelas de fundo preto ou como intervenções gráficas sobre as imagens. O extrato sonoro, por sua vez, é composto por: a) músicas; b) sons e ruídos diversos (como barulhos de explosões, tiros, gritos, uma intermitente máquina de escrever e efeitos de eco); c) comentários falados do próprio Godard; d) comentários em voz over emitidos por fontes extradiegéticas desconhecidas; e) diálogos gravados para a série e f) diálogos extraídos de filmes. De forma bem mais específica, Gervaiseau informa, partindo de uma tipologia criada por Jean Douchet, que podem figurar no extrato visual de História(s) do cinema:

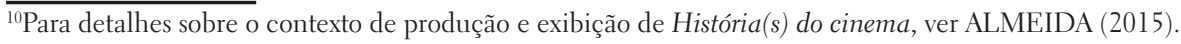




\begin{abstract}
1) imagens extraídas: dos mais diversos filmes de ficção, de documentários, de noticiários, de filmes de família, de filmes pornográficos; 2) reproduções de fotografias e quadros célebres e anônimos; 3 ) atores e atrizes especialmente convidados pelo cineasta, que dizem trechos de diversos textos selecionados e algumas vezes, mais simplesmente, meditam ou andam no intervalo entre duas leituras; 4) imagens do próprio cineasta, apoiado às prateleiras de sua biblioteca, retirando livros, dos quais consulta as capas e folheia as páginas, ou trabalhando à mesa de montagem ou, ainda, mais simplesmente, sentado e pensativo, charuto à boca; 5) além disso, podem coexistir, sobre essa mesma faixa, diversas imagens através de efeitos de mixagem e de sobreimpressão, assim como inscrições verbais: títulos de filmes, de romances, trocadilhos, notas musicais, palavras de ordem, expressões consagradas, palavras atrofiadas, trechos de críticas cinematográficas etc. (GERVAISEAU, 2012, p. 312)
\end{abstract}

Além dos materiais de arquivo - e imbricada neles - ganha destaque a presença física do próprio Godard, que é visto ora à mesa de montagem, ora à máquina de escrever, ora recitando textos ou mesmo em antigas fotografias. Apesar de articular a série de um modo que frequentemente omite os autores das obras das quais se vale, o cineasta se faz presente como montador que ordena o discurso e utiliza a sua própria imagem diante da máquina de escrever como uma espécie de metáfora visual que afirma sua condição de autor. A máquina de escrever se apresenta como um curiosa contradição em História(s) do cinema, como se Godard dissesse: "olha, quem escreve esta(s) história(s) sou eu”. Mas ao mesmo tempo, na prática, não é através do texto e muito menos na máquina que esta escrita se dá, e sim por meio de uma obra audiovisual que mistura imagem, palavras e sons.

Num jogo metalinguístico e intertextual em que há sempre muitos enigmas a serem decifrados e camadas a serem descobertas, o gesto arqueológico praticado por Godard opera de modo que o cineasta se constrói como uma grande consciência do cinema, uma espécie de grilo falante que surge para lembrar que a montagem é que dá a ver a realidade do mundo histórico, porque a memória é sempre lacunar e incompleta (do cinema, da história, do sujeito que a conta e do sujeito espectador). É como se os buracos presentes nesta história do cinema não-historiográfica funcionassem como uma "metáfora de montagem" elaborada por um Godard ciente das limitações do relato histórico e, especialmente, das limitações do relato histórico elaborado pelo cinema; alguém que sabe que a compreensão total de qualquer fato histórico é impossível. 


\section{Construindo aproximações entre a arqueologia crítica de Didi-Huberman e Warburg, Malraux e Godard}

Warburg desenvolve uma espécie de saber-montagem que se dá por meio de relações associativas, e nunca de forma linear, estável ou cronológica. Não resta estranho que alguns autores como Philippe Alain Michaud (2013) e o próprio Didi-Huberman (2013) enxerguem respingos dos procedimentos warburguianos no Godard de História(s) do cinema, que também pensa por montagem e associação.

Tanto Warburg quanto Godard vislumbraram uma potência da montagem que, ao colocar imagens em relação, explora tanto a questão da sobrevivência das imagens quanto um movimento no qual as imagens são necessariamente colocadas. Ainda que o conjunto de materiais dos quais tanto Warburg quanto Godard partem sejam naturalmente limitados, o exercício de montagem, desmontagem e remontagem é praticamente infinito. Isso ocorre pois novas correspondências sempre poderão ser feitas e novos sentidos delas emergirão.

Os olhares renovados em relação à arte e ao cinema e as metodologias heterodoxas que surgem a partir destas três experiências também só são possíveis no século XX em função das facilidades proporcionadas pela reprodutibilidade técnica e pelo surgimento de meios que já nascem reprodutíveis no século anterior - a fotografia e o cinema. Estes procedimentos associativos foram perpassados por um flagrante exercício de pensamento com imagens que se dá por meio da montagem e que é bastante próximo do que fez Godard em História(s) do cinema. Warburg e Malraux forneceram um repertório de experimentação visual e investigação sem o qual, provavelmente, a série de Godard não existiria como é. Não são os únicos fatores que determinam a existência de História(s) do cinema e as suas marcas autorais, pois a obra conjuga também um outro contexto, o das artes do vídeo, e trabalha também com imagens em movimento, e não apenas com fotografias. No entanto, no nível de uma pesquisa sobre as imagens, são experiências que guardam muitas similaridades.

Ao apropriar-se daquilo que compõe coleções e arquivos de imagens e obras pré-existentes exercitando um pensamento visual que se dá por meio da montagem, Warburg, Malraux e Godard também revelam o que subjaz como interesse fundamental das suas investigações. No ato de selecionar, que passa necessariamente também por excluir, os seus museus imaginários são postos em movimento dando a ver uma "arte da memória pessoal": aquilo que criaram e produziram opera, ao mesmo tempo, como ferramenta de investigação e inventário dos seus próprios interesses.

Por que cada um deles escolhe um determinado conjunto de imagens e 
obras e não outras? O que esta seleção revela sobre cada um? Talvez a resposta resida no fato de serem personagens cuja obra se confunde com a própria vida e se tornou projeto de uma vida inteira. Porém, como ocorre com Benjamin, as experiências dos artistas e intelectuais que são trazidas aqui ultrapassam um nível exclusivamente individual e apresentam-se também como registros de uma época, num movimento pendular em que o individual - que incluiria especialmente o selecionar e o apropriar-se, para além do colecionar - se oferece não apenas como escrita de si, mas também se abre ao mundo. E no gesto de selecionar e apropriar-se, há uma intenção de lidar com a memória do mundo através de alguns dos seus fragmentos (neste caso, imagens), e ainda assim lidar também com a memória pessoal de cada um.

Aqui todos eles se encontram mais uma vez, num flagrante paradoxo: ao mesmo tempo em que suas criações, sejam elas artísticas ou teóricas, expõem um tipo muito específico e destacado de modo de fazer que coloca o método no centro das atenções, conscientemente recusam qualquer propensão universalizante, inviabilizando que a sua prática, em si, se constitua como modelo a ser copiado ou aplicado em outros contextos ou circunstâncias de investigação.

\section{Referências}

AGAMBEN, G. "Aby Warburg e a ciência sem nome”. Revista Arte๒Ensaios, n. 19, 2009, p. 132-143.

ALMEIDA, G. Ensaio, montagem e arqueologia crítica das imagens: um olhar à série História(s) do cinema, de Jean-Luc Godard. Tese (Doutorado) - Universidade Federal do Rio Grande do Sul, Porto Alegre, 2015. Disponível em: https://www. lume.ufrgs.br/bitstream/handle/10183/119180/000970238.pdf?sequence=1. Acesso em 08/10/2016.

BENJAMIN, W. "Desempacotando minha biblioteca”. In: BENJAMIN, W. Obras escolhidas, vol. II - Rua de mão única. São Paulo: Brasiliense, 2012.

. Passagens. Belo Horizonte: Editora da UFMG, 2006.

DIDI-HUBERMAN, G. A imagem sobrevivente: história da arte e tempo dos fantasmas segundo Aby Warburg. Rio de Janeiro: Contraponto, 2013.

. Ante el tiempo. Historia del arte y anacronismo de las imágenes. Buenos Aires: Adriana Hidalgo editora, 2011.

. “Cascas". Serrote. Rio de Janeiro, n. 13, p. 99-133, mar. 2013 a.

Remontages du temps subi - L'oeil de l'histoire, 2. Paris: Minuit, 2010.

. "S'inquiéter devant chaque image (Entrevista concedida a Mathieu Potte-Bonneville e Pierre Zaoui)". Vacarme, n. 37, 2006. Disponível em: http://www. vacarme.org/article1210.html. Acesso em 22/05/2016. 
GERVAISEAU, H. O abrigo do tempo: abordagens cinematográficas da passagem do tempo. São Paulo: Alameda, 2012.

MALRAUX, A. Le musée imaginaire de la sculpture mondiale, vols. I-III. Paris: Gallimard/Galerie de la Pleiade, 1947-1954.

. "Museum Without Walls". In: MALRAUX, A. The Voices of Silence. St.

Albans: Paladin, 1974, p. 13-128.

MICHAUD, P.-A.. Aby Warburg e a imagem em movimento. Rio de Janeiro: Contraponto, 2013.

OVIEDO, A. "Nota preliminar". In: DIDI-HUBERMAN, G. Ante el tiempo. Historia del arte y anacronismo de las imágenes. Buenos Aires: Adriana Hidalgo editora, 2011 .

SELIGMANN-SILVA, M. “A escritura da memória: mostrar palavras e narrar imagens". Remate de Males - Revista do Departamento de Teoria Literária do IEL, UNICAMP, v. 26, n. 1, 2006, p. 31-45. Disponível em: http://revistas.iel.unicamp. br/index.php/remate/article/view/3282. Acesso em 10/01/2015.

. "Deletar arquivos, apagar o passado: ars oblivionalis, entre a necessidade e a resistência”. Cadernos AEL: Anistia e direitos humanos, UNICAMP/IFCH/AEL, v.13, n. 24/25, p. 97-1 17, 2008. Disponível em: http://segall.ifch.unicamp.br/publicacoes_ael/index.php/cadernos_ael/article/viewFile/39/46. Acesso em 10/01/2015.

WARBURG, A. Atlas Mnemosyne. Madri: Akal, 2010.

\section{Referências audiovisuais}

HISTÓRIA(S) do Cinema. Direção, roteiro e montagem: Jean-Luc Godard. França, 1988-1998, colorido, 268 minutos. Edição em DVD consultada: Midas Filmes, Portugal, 2007. 